K 461

A5

909

opy 1

\title{
TEST VIRGINIA
}

FOREST, GAME AND

FISH IAWS

\section{AND}

THE LACY BIRD LAW

(FEDERAL LAW)

1909.

J. A. VIQUESNEY, WARDEN BHLINGTON. 



\section{WEST VIRGINIA Laws,}

FOREST, GAME AND

\section{FISH LAWS}

\section{AND}

\section{THE LACO BIRD LAW \\ (FEDERAL LAW)}

\section{9.}

J. A. VIQUESNEY, WARDEN, BELINGTON.

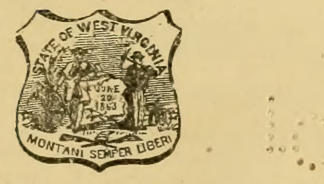

NEWS-MAIL COMPANY

State Printers. 1909. 


$$
\begin{gathered}
54^{61} \\
.5^{5} \\
1909
\end{gathered}
$$

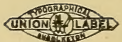

\section{OF D. \\ JAN 41910}




\section{FOREST, GAME AND FISH}

\section{ILAWS.}

Sec.

1. Forest, game and fish warden; term of office; compensation; report of mileage: deputy wardens, their compensation; ex-officio deputy wardens, their jurisdiction and compensation.

2. To have oharge of certain public matters and powers therefor. biennial report to Governor.

3. Authority and duties of chief deputy and deputy wardens; penalty for violation of certain acts.

4. Power to arrest for violations; penalty for neglect of duty.

5. Seizure of fish, game or birds.

6. Bonds required from certain officers.

7. Regarding dogs; any person may kill; when.

8. Regarding dogs; when owner or keeper is liable; to recover in action before any justice or court; penalty for harboring or secreting certain dogs.

9. Regarding dogs; when owner to cause certain dogs to be killed; penalty for failure to do so.

$9 a$ 1. Duty of assessor.

9 a 2. County court to levy per capita tax.

$9 a$ 3. Per capita tax; how collected, commission allowed sheriff.

$9 a-4$. Court to cause list of persons failing to pay; duty' to constables.

$9 a-5$. Complaint before justice; appraisers to be appointed; report to whom.

$9 a-6$. Sheriff to report to county court, when;

$9 a-7$. Appraisers not to certify appraisement, when.

9a-8. Dogs deemed property, when.

9a-9. Penalty for concealing dog to avoid tax. 10. Stationery and postage; how provided; how paid for.

11. May employ attorney to aid in prosecutions. - 12. Powers to search persons, cars, etc. 
13. Court or justice shall issue search warrant: sale of goods seized; disposition of proceeds of sale.

14. Right to summon aid in making arrest; penalty for refusal to act; arrest on Sunday.

15. Report of deputy wardens; ex-officio wardens; justices; when made.

16. Penalty for false return as to moneys collected.

17. Penalty for interference with wardens.

18. Title to wild game, etc., in state.

19. License to hunt; how procured; license fees; to whom paid; penalty for failure to produce license; owners of land may exchange hunting privileges; consent of guardian required for minors; penalties for violations of section.

20. Protection of skunk; penalty; prosecutions; power of justices; presumption of guilt.

21. Penalty for transfer or sale of license.

22. Closed season; open season.

23. Game animals; what are considered.

24. Deer; when to kill; shall not chase with dogs ; penalties for transportation of game beyond limits of state.

25. Rabbits, when unlawful to kill or injure in certain counties; season for killing certain animals and birds; number allowed killed; unlawful to trap, snare,. etc.; penaity for violation of section; may capture for purpose of propagation.

27. Unlawful to catch by seine, trap, etc.

28. Unlawful to hunt, kill or pursue on Sunday; penalty for violations.

29. Prosecutions to be in name of state; fee allowed prosecuting attorney.

30. Witnesses; when incompetent.

31. Moneys collected for violations; how disposed of.

32. Requisition and extradition expenses.

33. What considered game birds.

34. Destruction of eggs and nests.

35. Shall not transport.

36. Penalty for violations sections $33,34,35$.

37. Right to take birds, etc., for scientific purposes.

38. Certificate to collect birds, etc.; to and by whom issued; how secured; fee to be paid; penalty for violations.

39. Certificate; when expires; not transferable.

40. Birds not protected. 
41. Wild non-game birds as domestic pets.

42. Accidental shooting of human being or live stock; penalty for.

43. No open season for certain birds; penalty for violation of section.

44. Fish; how to catch; where can seine; when; registry of seines; length of fish caught; how to measure; certain season in certain counties; lawful to catch suckers; owners may take from private pond; letting water out of pond; penalty therefor; erection of trespass signs; penalty for violation of provisions of section.

45. Lawful to destroy nets, traps, etc.; unlawful to have seines in possession; penalty provided; obstruction of water course; construction of ladder under supervision; violation of provisions; time limit construction of ladder or way.

46. Unlawful to employ for purpose of killing; serving by hotel: penalty.

47. Use of dynamite, etc., penalty.

48. Unlawful to sell explosives for purpose of killing; penalty therefor.

49. Unlawful to build fires in connection with hunting, etc.; permission in writing; from whom; penalty for violation; owner et al may arrest.

50. Unlawful to shoot across public road; near school house; on lands of another; near occupied dwelling house; penalty.

51. Warden shall be ex-officio fire warden; deputies to extinguish fires: means used: may hire volunteers; forfeit for refusal to serve; report origin of fire; amount expended putting out.

52. Deputy wardens; compensation of; services at forest fires; court to fix wage; charge against county; statement of deputy to county court.

53. Fires built in forest; failure to extinguish: penalty for violation; willful frring of woods; penalty.

54. Railroad right-of-way; removal of inflammable materials; when; shall provide spark arresters; prevent escape of fire from furnace; shall not deposit ashes on tracks or right of way; trainmen to report fires; to whom; violation of provisions by employee; penalty.

55. Warden to recover damages; no bar to right of individuals to recover. 
Sec. 1. The governor shall between the first day of June and the first day of July, one thousand nine hundred and nine, appoint-some person, a citizen of this state, whose term of office shall begin on the first day of July, one thousand nine hundred and nine, to the office of forest, game and fish warden. Said warden shall hold this office for four yert: and intil nis successor has. been appointed arid qualified, unlas sconer removed for cause by the governor. He shall receive for his services the sum of eighteen hundred dollars per annum, to be paid out of the treasury, quarterly, after being duly audited; and shall be allowed mileage of three cents a mile while traveling by railroas or steamboat, and ten cents a mile while traveling otherwise than by railroad or stesminat, for the distance necessarily traveled while actually in the discharge of his official duties as such warden. Provided, however, that the mileage expenses of said warden shall be reported quarterly under oath to the governor and approved by him; and provided, further, that such mileage expenses shall not, in any one year exceed five hundred dollars. Said warden shall devote all of his time to the discharge of the duties of his office, imposed upon him by law. Said warden shall appoint two persons who are citizens of this state and one of whom shall reside in the 
eastern section of the state, chief deputy wardens of forest, game and fish, said chief deputies shall hold their office at the pleasure of the warden appointing them. Said chief deputies shall each receive for their services the sum of nine hundred dollars a year to be paid out of the treasury quarterly after being duly audited, and shall be allowed mileage of three cents a mile while traveling by railroad or steamboat, and ten cents a mile while traveling otherwise than by railroad or steamboat for the distance necessarily traveled for the purpose of performing the duties imposed upon them by law, and they shall devote all their time thereto, such mileage expenses of either of said chief deputies shall be reported quarterly under oath to the warden and approved by him, and forwarded to the governor and approved by him; provided, however, that said mileage in any one year shall not exceed four hundred dollars to each chief deputy warden. The warden shall appoint such persons as he may deem fit, who are citizens of this state, to act as deputy. wardens in the several counties of this state. Said deputy wardens shall hold their office at the pleasure of the forest. game and fish warden. The sheriffs, deputy sheriffs and constables in the several counties of this state shall be ex-officio deputy wardens therein, and the chiefs of police of 
the cities, towns and villages of this state shall also be ex-officio deputy wardens therein and their jurisaiction shall extend no further than their respective counties, cities, towns and villages. All said deputy wardens, either appointed or ex-officio, shall receive for their services one-half of the fines imposed by any justice or court having jurisdiction, and collected in each prosecution, instituted by any such deputy warden, and the other half of such fine shall be paid to forest, game and fish warden, who shall pay the same over to the treasurer of the state to be credited by him as other fines are credited; but no fees or moneys shall be paid any deputy for services rendered as such deputy warden, out of the treasury of this state, and in any prosecution under this chapter, section two of chapter thirty-six of the Code of 1899 and section 1159 of the Code of 1906 shall not apply to any warden.

Sec. 2. The forest, game and fish warden shall have general charge of the following public matters, and necessary powers therefor: The collection and diffusion of such statistics, literature and information as he may deem useful in regard to the protection of forests and the protection and propagation of game and fish, the publishing thereof, and the taking charge of and keeping all reports, books, papers and documents which 
shall, in the discharge of his duties hereunder, rome into his possession and control, and the institution of all proper legal proceedings to enforce the provisions of law, now in force, or hereafter enacted, in reference to forest. game and fish. Said warden shall, on or before the first day of January, 1911, and biennially thereafter, submit to thie governor, a detailed report showing what has been done by him during the preceding biennial period, the amount of all moneys received by him and from what sources, in detail, a complete inventory of all game and other property seized and sold and the amount received therefor and the amount of disbursements in detail. The boolis and vouchers of said warden shall be suhject to examination by the auditor of the state at all times.

Sec. 3. The chief deputy and deputy warciens shall act and be under the direction and supervision of said forest, game and fish warrlen. Said chief deputy and ceputy warlens shall have authority, and it shall be their duty, to enforce the game, fish and forest laws of this state, now in force or hereafter enacterl, for the protection of forests and protection. preservation of game, fish and birds, and shall be imm diately responsible to the warden. and shall report all matters under their ay isdiction whenever requested by him and receive in 
structions from him. It shall be unlawful for any deputy warden, either appointed or ex-officio, to settle, compromise or adjust any prosecution under this chapter and to receive moneys from any violator or alleged violator of any of the provisions thereof, unless the same are moneys received in the payment of fines imposed in due process of law by a justice or court having jurisdiction of the offense charged, and if any such deputy warden shall receive any moneys from any such violator or alleged violator, either as such settlement and compromise or to prevent any prosecution therefor, such deputy warden shall be guilty of a felony and upon conviction thereof, shall be confined in the penitentiary not less than one nor more than five years.

Sec. 4. The forest, game and fish warden, and appointed deputy wardens shall have full power to execute and serve any warrant or process of law, issued by any justice of the peace or by any court having jurisdiction under the law, relating to game, fish, birds and forests in the same manner as any constable or sheriff might serve or execute such process, and may arrest on sight without a warrant, any person or persons, detected by them actually violating tany of the provisions of the laws of this state relating to the game, fish, birds and forests, and may take such per- 
son or per'sons, so offending, before any court, or justice of the peace, having jurisriction of the offense, and make proper complaint before such court, or justice, which shall proceed with the case in the manner as provided by law. Any such appointed warden, who on receiving information from a reliable person, of the violation of the game, fish or forest laws, neglects or refuses to thoroughly investigate such alleged violation, and apprehend or attempt to apprehend the offender, shall be guilty of a misdemeanor and upon conviction thereof, shall be fined not less than ten dollars nor more than fifty dollars for each offense.

Sec. 5. The warden and deputy wardens shall seize and take possession of, on sight and without process, any fish, game or birds found in the possession of any person or persons, or corporation which is so in possession contrary to law.

Sec. 6. The forest, game and fish warden and the chief deputy wardens shall each before entering upon the discharge of their respective duties, execute a bond, the warden in the penalty of three thousand dollars and the chief deputies in the penalty of one thousand dollars with security thenes in to be approved by the governor, and conditioned for the faithful perfomiance of their duties, and to accounteifor and pay 
over all moneys and property coming into their hands, due and belonging to the state, which said bondis, after having been anproved by the governor, shall be deposited with the auditor.

Sec. 7. Any person may kill any cog that he may see chasing, worrying, wounding or kiling any sheep, lambs, goats or kids outside of the enclosure of the owner of such dog, unless the same be done by the direction of the owner of such sheep, lamps, goats or kids.

Sec. 8. If any dog shall have killed or assisted in killing, wounding or worrying any sheep, lambs, goats or kids ont of the enclosure of the owner of such dog, the owner or keeper of such dog shall be liable to the owner of such sheep, lambs, goats or kids in the amount of the damages sustained, to be recovered in action kefore any court or justice having jurisdiction of suci action; and it shall not be necessary to ustain in such action, to prove thai the owner or lieeper of such dog, knew such dog was accustomed to do such worrying, killing or wounding; but a recovery under - this section shall bar and preclnde the owner of such sheep. lambs, goats or kids frem ohtaining compensation from tle county ourt. and when compensation is owtained from the county court under any law whichos now or may hereafter be in 
force. then the county wherein the payment is made, is authorized to sue under this section, and recover as the owner of the sheep, lambs, goats or kids, might have done, and the amount so recovered shall be paid into the connty treasury: but no suit shall te commenced unless authorizta by the county court. Any person who shall harbor or secret or aid in secreting any dog which he knows or has reason to believe has worried. chased or killed any sheep, lamibs, goats or kids, not the property of the owner of such dog, out of his enclosure, or knowingly permits the same to be done on any premises under his control, shall be suilty of a misdemeanor, and upon conviction thereof before any court or justire having jurisdiction thereof, in the count: in which the ofiense is committed, be fined not less than ten iollars nor more than fifty dollars, and at the discretion of the court or justice. imprisoned in the county jail not more than thirty days; and each day that such dog is harbored, kept or secreter, shall constitute a separate oftense.

Sec. 9. The owner ar keeper of any dog that has been worrying. Wounding. chasing or killing any sheep. lambs, goats or kids. not the property of such owner or keeper, out of his enclosure shall, "ithin forty-eight hours after having received notice thereof in writing from reliable and trusty source. 
under oath, cause such dog to be killed; if the owner or keeper refuse to kill said dog as hereinbefore provided, any justice of the peace upon information, shall summon the owner or keeper of said dog, and after receiving satisfactory proof that his dog did the mischief, shall issue a warrant on application being made by the owner of the sheep, lambs, goats or kids killed, and give it into the hands of the constable, special constable or sheriff, who shall ixill the dog forthwith; the cost of said proceedingis shall be paid by the owner of the dog sn killed, including a fee of fifty cents to the officer killing the said dog; the owner of said dog killed, shall in addition to the costs, be liable to the owner of the sheep, lambs, goats or kids, or to the county court for the value of the sheep, lamins, goats or kids so killed or injured.

Sec. $9 a-1$. 'That it shall be the duty of every assessor, annually, to list all dogs over four months old owned or kept within his district, particularly. noting the number owned or kept about any one house, giving such description of each as he can conveniently obtain, distinguishing between males and females, and for this purpose he may examine on oath any person found in his district; the fact that any dog is kept or allowed to remain about any house shall he deemed sufficient evidence to authorize 
the assessor to return the person inhabiting said house as the owner of such dog; such list shall be returned by the assessor to the clerk of the county court of his county, on or before the time fixed for levying the county levy in each year; the assessor shall receive as compensation the sum of five vents for each dog so listed.

That is shall be lawful, if he so choose. for the owner of any dog to have the same listed by the county assessor of any county in this state. the same as all other personal property is listed and taxed; and when the nwner of any such dog shall have paid the taxes assessed against the same, such dog shall he demed property in the meaning of the law.

Any person who shall wilfully or ma1; ziously steal, poison, wound or kill any such dog or dogs listed as personal property as aforesaid, shall upon conviction be punished as provided by law for stealing, poisoning, wounding or killing other property: and the owner of such dog or dogs, so stolen, wounded, poisoned or killed, after complying with the provisions of this act, may have a right of action in damages against any such person or persons guilty of a violation of the provisions of this act for the sum not exceeding the assessed. value of such dog or dogs.

But nothing in this act shall prevent the 
killing of any vicious or dangerous dog off tho premises and out of control of the owner; nor the killing of any dog running at large and out of the control of the owner thernof, after such owner shall have had notice and still permits such dog to run at large and out of his control; and no person shall be liable in damages or to prosecution by reason of any such killing. Sec. 9x-2. The county court shall annual1y levy a per capita tax on every male dog foir months oid and over, of fifty cents; on every spayed female dog of four months old and over, of fifty cents, and on every unsjayed female dog four months old and over, of one dollar and fifty cents.

Sec. 9a-3. The per carita tax imposed upon the dogs of any county, shall be collected and accounted for by the sheriff of such county, as county levies are collected and accounted for, and to that end it shall be the duty of the court, in convenient time, to cause a list to be delivered to such sheriff containing the names of all persons charged with a percapita tax on dogs, and the smount assessed against each; for collecting, accounting for and paying out the per carita dog tax, the sheriff shall be allowed the like commission as allowed for collecting and accounting for the county levies; movided, however, that for so much thereof as he receives from the constables upon the 
list provided for by the next section, he shall for accounting for and paying out the same be allowed one-half commission; the sheriff shall have charge of all the moneys accruing from the per capita tax upon dog's. or for fines imposed under this act, collected within his county; and the same shall constitute a fund for remunerating the inhabitants thereof for any loss they may sustain hy injury done to their sheep, lambs, goats or kids by dogs within their county; whenever the surplus arising from any such fund at the end of any fiscal year shall exceed one-half of the amount expended therefrom, for the preceding year, the county court of any county shall apply such excess to the general road fund of such county.

Sec. $9 a-4$. The court shall cause a list of all persons failing to pay the per capita dog tax assessed against them, and by the sheriff returned delinquent for non-payment of percapita dog tax, to be delivered to the constables of the district in which they reside with the number of dogs listed to each, and amount of per capita tax assessed severally against each. In case any person liable for said tax shall fail or refuse to pay such amount to the constable upon application therefor, the constable shall levy upon and take into his possession property or effects of the delinquent (including said dog or dogs so listed if such are to be found) suffi- 
cient to pay said amount and the cost of levy and sale; the first item in said sale to be the said dog or dogs so taken. In case such constable be unable to sell such dog or dogs; or unable to collect the tax thereon, by the sale of other property, he shall kill and bury such dog or dogs and shall be allowed a fee of one dollar for killing and burying each dog; such fee to be paid by the county court, out of such per capita dog tax, when a proper return has been made by such constable. The constable shall have as to said capitation dog tax, the powers of levy and sale and of collection by any method as is vested in the sheriff for the collection of taxes.

Any person who shall conceal a dog for the purpose of evading the provisions of this section shall pay a fine of five dollars. Where there is more than one constable in rhe district, the court shall decide which shall act and each constable receiving such list shall make due return to his county court, at such time as the court shall direct, of the manner in which he has discharged the duties respecting the same, and shall pay over to the sheriff any taxes or fines collected by him, taking duplicate receipts therefor, one of which he shall file with the clerk of the county court, who shall charge the sheriff with the amount of the same; each constable shall be liable for the per- 
capita tax assessed upon every dog enumerated in such list, of which he shall fail to return a satisfactory account to the court. The constables and their securities shall be liable on their official bond, upon motion of the circuit court of their respective counties for any money received by them which they may be liable to pay by virtue of this act.

Sec. $9 a-5$. The county court of any county shall, upon the petition of ten per cent. of the legal voters of such county being filed in such court, asking a vote to be taken upon the question, order such vote to be taken at the next succeeding general or school election, to ascertain, the sense of tho voters of such county. If a majority of all the votes cast on that question at said election be against imposing a tax on dogs, then this act shall cease to be in force in such county from and after the day on which such result is declared.

If proof can be established that any dog or dogs helonging to a person living within a county where the dog tax is not assessed and collected, kill any sheep, lambs, goats . or kids within a county where the dog tax law is in force, the owner of such dog or rogs shall be liable to the owner of such sheep, lambs, goats or kids so killed, for the amount of damage caused by such dog or dogs. If such collection cannot be made by law from the owner of such dog or dogs then 
the county court of such county wherein the said dog or dogs belong shall be liable for the payment of such damages to be paid out of the general expense fund of said county. Sec. $9 a-6$. At the end of every year, or at such times as the county court may direct, the sheriff shall report to the court the amount of money in his hands, arising from the tax on dogs, and from fines imposed under this act, and for which he is accountable; the county court shall, then, out of said fund, provide for the payment of the expenses of assessing, levying and collecting said tax, and shall at the same time, or as soon thereafter as practicable, andit the claims reported under section five of this act, and allow each claim in full, or so much thereof as the court may deem just and right; and after auditing such claims as should be paid out of said fund, if the fund be sufficient to pay the whole thereof, shall give orders thereon to the persons entitled thereto, to be paid by the sheriff out of said fund. But if it shall appear that there is not sufficient funds in the hands of the sheriff to pay the amount of claims audited, the court shall give such orders as will divide the fund pro rata amongst those entitled thereto.

Sec. $9 a-7$. That appraisers to be appointed under section five, shall not certify any aptraisement to the court unless it be 
proved to their satisfaction that the person claiming such damages has made a proper return to the assessor of the dogs owned or kept by him.

Sec. 9a-8. All dogs on which taxes are paid are hereby deemed property in the mcaning of the criminal law. But this chapter shall not be construed as repealing or in any manner modifying chapter thirtytwo of the Acts of 1875 .

Sec. $9 a-9$. If any person shall conceal his dog, or send him from house to house, or to any place for the purpose of avoiding the tax, he shall pay a fine of five dollars. All fines imposed by this act shall be recovered by suit in the name of the State before a justice, as debts of like amount are by law recoverable, to be paid into the county treasury to the credit of the fund above mentioned; provided, that no costs of such proceedings shall be paid out of the county treasury.

Sec. 10. The forest, game and fish warden shall be allowed all necessary printing, printed blanks, stationery and postage; but before he shall incur any expense for printing he shall first make requisition therefor upon the governor, who, in his discretion, approving the same, shall issue his warrant to the warden for said printing, the cost and expense therefor to be paid out of the treasury. 
Sec. 11. The forest, game and fish warden and deputy wardens may make, complaint and cause proceedings to be institutent-against any person, or persons, or corporation, for the violation of any of the game, fish, bird and forest laws without the sanction of the prosecuting attorney of the county wherein such proceedings are instituted; and in all such cases they shall not be required to give security for costs. Any of said officers may also appęar in any court of competent jurisdiction in this state, in any case for violation of any of the laws for the protection of forests, or the protection, preservation and propagation of game, fish and birds, and prosecute the same in the manner and with the same authority as the prosecuting attorney of the county in which such proceedings are had. And in such cases they may, in the event of the refusal or neglect of the prosecuting attorney to act, employ an attorney of their choice, and to such attorney, or to the prosecuting attorney if he shall act, there shall be taxed in the costs, upon conviction, a fee of ten dollars in such case.

Sec. 12. The forest, game and fish warden and deputy wardens shall have the power to search any person and examine any boat, vehicle, conveyance, express car, railroad car, fish box, fish basket, game bag or game coat, or any other receptacle in which 
game, birds or fish could be placed, concealed or conveyed, whenever they have reason to believe that they will secure or discover evidence of a vilolation of the game and fish laws of this state; and any hindrance or interference, or attempt to hinder or interfere, with such search and examination, shall be prima facie evidence of a violation of the law by the person or persons who hinder or interfere, or attempt to hinder or interfere, with such search and examination. Said officer, or officers, shall, at any and all times, seize and take possession of any and all game, fish, birds and animals which have been caught, taken or killed at any time, in any manner or for any purpose, or had in possession or under control or have been shipped, contrary to any of the laws of this state. Such search and seizure may be made without warrant; and the warden or deputy wardens shall not be liable for false seizure of such birđ̄s, game or fish.

Sec. 13. That any justice or court having jurisdiction of the oftense, upon receiving information of probable cause for believing that any game, birds or fish, caught, taken, killed, had in possession, under control, or shipped, contrary to or in violation of any of the laws of this state, shall issue a search warrant, and cause a search to be made, in the manner provided by law, in any place, 
and to that end may cause any buildings, dwelling house, enclosure, or car to be entered forcibly, if necessary, and any apartment, chest, barlocker, refrigerator, crate, basket or package, broken open and the contents thereof examined by the forest, game and fish warden or deputy wardens. All game, fish or birds, seized by any of said officers, shall be sold under the direction of the justice or court before whom the offense is tried, or search warrant issued, and the proceeds of all sales shall be paid into the treasury of the state.

Sec. 14. Any of the officers herein, whose duty it is to enforce the gime, fish, bird and forest laws of this state, shall have the same right and power as sheriffs to summon aid in making arrests, seizures, or executing any process; and any person, or persons, so summoned, and refusing to act, shall be liable, upon conviction, to the same fines and penalties, the same as if summoned by a sheriff. Such arrest may be made on a 'Sunday, in which case the person, or persons, arrested shall be taken before a justice, having jurisdiction, and proceeded against as soon as may be on a week day following such arrest.

Sec. 15. The appointed deputy wardens shall, on the first of the months of February, June, September and December of each year make a report under oath to the for- 
est, game and fish warden which reports shall show in detail the work done by them severally during the three months next preceding. The forest, game and fish warden shall furnish the deputy wardens all necessary blank forms and stationery for making sairl reports. All such reports shall show an account of the suits commenced, the justice or court before whom such proceedings were had, the number and kinds of game, fish, birds and property, seized, and what disposition was made of the same, the amounts of proceeds of sale, and the amount of money, if any, received by him for fines imposed, or from any other source provided for by this chapter. All ex-officio deputy wardens shall make a report to the forest, game and fish warden on the first days of February, June, September and December of each year if they have instituted any proceedings or collected any moneys under the provisions of this chapter during such preceding three months, and all deputy wardens shall within thirty days after its receipt pay over to the forest, game and fish warden the fines collected by him, and the bonds of ail ex-officio wardens shall be liable for any such moneys received by them. All justices and judges before whose courts any case under this chapter comes shall on the first day of February, June, September and December, of each year, if there has 
been before this court any case under this chapter, report to the state forest, game and fish warden all money collected by him and the status of all cases pending or started in his court.

Sec. $15 a$. It shall be unlawful for any person to have in his possession for the purpose of using, or to use a ferret for the purpose of catching rabbits or driving them from their burrows. Any person convicted of an offence under this section shall be fined not less than five nor more than twenty dollars for each offense."

Sec. 16. The forest, game and fish warden and deputy wardens, or any other offcer who shall make any false return as to moneys collected or disbursed by him, as provided for in this chapter or does not pay over to the proper officer as provided in this chapter, moneys collected by him for fines shall be deemed guilty of a felony, and upon conviction thereof shall be confined in the penitentiary not less than one year nor more than five years.

Sec. 17. Any person who hinders, obstructs or interferes with, or attempts to hinder, obstruct or interfere with, the forest, game and fish warden and deputy wardens in the discharge of any of their respective duties herein, shall be demed guilty of a misdemeanor, and upon conviction 
thereof shall be fined not less than twentyfive dollars nor more than two hundred dollars, together with the costs of the prosecution, and in default of payment thereof shall be confined in the county jail until said fines and costs are paid; Provided, however, that such imprisonment shall not exceed ninety days.

Sec. 18. The ownership of, and the title to, all wild game, wild birds, both resident and migratory, and all fishes in the state of West Virginia, are hereby declared to be in the state, and no such game, birds, or fishes, shall be taken or killed in any manner, or at any time, except the person so taking or killing the same shall consent that the title thereto shall be and remain in the state of West Virginia, for the purpose of regulating the use and disposition of the same after such taking or killing. The taking or killing of wild game, birds or fishes, at any time or in any manner or by any person, shall be deemed a consent of such person that the title thereto shall be and remain in the state, for the purpose of regulating the use, and disposition of the same.

Sec. 19. No person, or persons, shall, at any time, hunt, pursue, kill or catch any wild game animals, or wild game birds in this state, without first having secured a license so to do, and then only during the 
respective periods when it shall be lawful to hunt such game animals and game birds. Such license shall be procured in the following manner, to-wit:

'The applicant shall go before the county clerk of the county and fill out a blank application, stating his name, age, occupation or profession, weight, height, place of residence, color of hair, eyes and complexion; the application shall be subscribed in ink and sworn to by the applicant, that his statements are correct and true to the best of his knowledge and belief, before the county clerk issuing said license; the applicant, if a non-resident of this state, or unnaturalized foreign born resident, shall pay to said county clerk the sum of fifteen dollars, as a license tax, and a fee of fifty cents to said clerk for issuing such license; if the applicant is a bona fide resident citizen of this state, he shali pay to the county clerk issuing such license, the sum of seventyfive cents as a license tax, and a fee of twenty-five cents to said clerk as his fee for issuing such license; provided, that such bona fide resident may fill out said application and swear to the same before a notary public or justice of the peace in the county of his residence and send same to the county clerk, together with such tax and fee and such clerk shall send him such license. Said license shall bear the seal of 
the county court of the county in which same is issued and signed by the clerk. All such license taxes shall be paid by the county clerk to the state treasurer on the first day of each month for the next month preceding. Such license shall entitle the person to whom it is issued to hunt and kill game in any county within this state at any time when it shall be lawful to hunt, pursue and kill such game; and no person, to whom such license has been issued, shall be entitled to hunt, pursue or kill game in this state, without at the time of such hunting, pursuing, or killing of game, he shall have such license in his possession; and he shall exhibit the same to any officer of this state, or owner, tenant or lessee of any land on which such person, or persons are hunting, on demand. All such licenses shall be good and valid for the period of one year next succeeding its issue. The carrying of any uncased gun in any of the fields or woods of this state by any person not having the lawful right to hunt, pursue or kill game, birds or animals in such fields or woods, shall as to such person, other than the bona fide owner, or owners of such fields or woods, his or their child or children, tenant or tenants, lessee or lessees, be deemed prima facie evidence of a violation of this section; and any person claiming to hold a license to hunt in this state, having in his 
possession any gun or other hunting paraphernalia in such woods, or fields, shall on failure to produce such license for inspection to any warden of this state or owner or agent of the owner of such woods and fields on demand, be deemed guilty of a misdemeanor and shall be punished on conviction as provided later in this section. Provided, however, that any resident owner, or owners, of farm lands, their resident child or children, or bona fide tenants, shall have the right to hunt, kill and pursue birds and game on such farm lands of which he, or they, are the bona fide owners or tenants, during the season when it is lawful to kill, catch or pursue birds or game, without securing such resident license; and provided, further, that the owners of adjoining lands may each have the privilege of reciprocating the non-licensed privilege by giving each other written privilege to exchange hunting rights only on land immediately joining each other and upon which each party resides. All non-resident members, of any club or organization, owning or leasing a game preserve, in this state, shall each be required to secure a non-resident hunters' license. Any person found guilty of violating any of the provisions of this section shall be deemed guilty of a misdemeanor, and upon conviction thereof, shall be fined not less than twenty-five dollars nor more 
than fifty dollars for each and every offense, in addition to the costs of the prosecution, and in addition thereto may be confined in the county jail for a period not exceeding thirty days, in the discretion of the justice or court trying the case, and upon failure of payment of fine and costs the person, or persons, convicted shall be confined in the county jail until such fines and costs are paid, but such imprisonment shall not exceed twenty days for any one offense. No hunter's license shall be issued to any minor under the age of fifteen years without the consent in writing from the parent or guardian of such minor, such consent to be filed by the clerk issuing such license.

Sec. 20. It shall be unlawful for any person, at any time, to catch, kill or injure, or to pursue with intent to catch, kill or injure, the skunk or polecat, except in defense of property, in any county of this state; provided, that before this act shall go into effect it shall be ratified by a majority of the voters in any county of the state which desires its adoption; and upon the petition of one hundred or more voters of a county to the county court thereof the said court shall submit the question of its adoption therein to the voters of that county, to be voted upon at a general election to be held therein, and shall cause 
to be printed upon the ballots used in such election the words, "For the skunk law," and "Against the skunk law," and if a majority of the votes cast be in favor of said law then the said court shall declare the same to be the law of that county and enter the same of record.

And in any county where this act has been adopted, as herein provided, and it is desired at any time thereafter to repeal the same, in such county, it may be done in the same manner as is provided herein for the adoption of this act.

Any person violating this section shall be guilty of a misdemeanor, and upon conviction thereof shall be fined not less than ten dollars, nor more than fifty dollars, and may, at. the discretion of the court or justice trying the case, be confined in jail not more than thirty days. Any justice of the peace, for the county in which the offense was committed, shall have concurrent jurisdiction, of all offenses under this section. Any person found with any recently killed skunk or polecat skins in his possession shall be presumed to have killed the same.

Sec. 21. Any person who shall; at any time, alter or change in any manner, or loan, sell or transfer to another any license provided for in section nineteen of this chapter or the person buying or borrowing 
such license, shall be deemed guilty of a misdemeanor and upon conviction thereof shall be fined not less than twenty nor more than fifty dollars and in addition thereto may be confined in the county jail not more than thirty days.

Sec. 22. The words "close season," and "close time," shall mean the time or period during which it is unlawful to hunt, pursue, catch, shoot, wound, trap or destroy any bird or animal, or to fish for or catch any fish, and the words "open season" and "open time," shall mean the open time or period during which it shall be unlawful to take these animals, birds and fish, as specified and limited by law.

Sec. 23. For the purposes of this chapter the following are considered game animmals, to-wit: deer and squirrel. And the following shall be considered game birds, to-wit: The anatadae, commonly known as ducks, geese, swan and brant; the raillidae, commonly known as mud hens, rails, coots, and gallinules; the limicolae, commonly known as shore birds, plover, snipe, wood cock, tattlers, curlews, ortolan, sandpiper; and gallinae, commonly known as wild turkey, ruffed grouse or pheasant, quail or bob white.

Sec. 24. It shall be unlawful for any person to buy, sell or have in possession any of the animals, wild fowl or birds mentioned in section twenty-three of this chapter, 
at any time when the killing, trapping, netting and snaring of such animals, wild fowl or birds shall be unlawful, or which shall have been killed, trapped, netted or snared contrary to the provisions of this chapter, And it shall further be unlawful for any person or persons, firm or corporation, at any time, to purchase or offer to purchase or to sell or to expose for sale, or have in his, or their possession for the purpose of selling, any quail, ruffed grouse, or pheasant, wood cock, wild turkey, wild goose, swan, brant, wild ducks of any kind, plover, snipe, sand piper, squirrel, deer or venison; trout of any species, salmon of any species, pike, bass or silver perch or any of the birds, fish or game prohibited to be caught or killed at any time by the provisions of this chapter, and it shall be unlawful for any person or persons, firm or corporation, or common carrier, to receive for transportation, or to transport, carry or convey, any quail, ruffed grouse or pheasant, wood cock, wild turkey, wild geese, swan, brant, wild ducks of any kind, 'plover, snipe, sand piper, squirrel, deer or venison or game fishes, mentioned in this section that shall have been caught, snared, taken, trapped or killed at any time, within the limits of this state, knowing, or having reason to believe, the same had been sold, or to transport, carry or convey the same outside of this state for 
any purpose. Provided, that it shall be lawful to have any such game animals, birds or fishes in possession for a period not exceeding twenty days after the open season thercof is ended and the close season thereon has begun. Any person, or persons, firm or corporation, guilty of violating any of the provisions of this section shall be deemed guilty of a misdemeanor, and on conviction thereof, shall be fined not less than twenty-five dollars nor more than one hundred dollars for each and every offense, and the costs of the prosecution. And in default of the payment of such fine and costs shall be confined in the county jail until the same is paid, not to exceed, however, the period of sixty days. The selling, exposing for sale, having in possession for sale, transporting or carrying and conveying, contrary to the provisions of this section, of each and every animal, fish or bird mentioned in this section, shall constitute a separate offense.

Sec. 25. No person shall hunt, chase, kill or wound any deer, from the first day of December, until the fifteenth day of October following, of any year, except tame deer owned by the person killing the same; nor shall any one person kill more than two deer in any one season. No person, or persons, shall chase or hunt deer with dogs in this state at any time. No person shall at 
any time kill any fawn, doe or any deer other than bucks with horns or antlers over four inches in length, or have the fresh skin of any fawn in his possession. No person shall at any time, kill or have in his possession any deer, quail, pheasant, or ruffed grouse, wild turkey, squirrel or any part of the same, or game fishes with the intention of sending or transporting the same or having the same sent or transported beyond the limits of this state. Any person violating any provision of this section shall be guilty of a misdemeanor and on conviction thereof shall be fined not less than twentyfive nor more than fifty dollars for each and every deer unlawfully hunted, chased, wounded or killed, and for each fawn skin had in possession, and not less than twenty dollars nor more than fifty dollars for each and every quail, ruffed grouse or pheasant, wild turkey or any part of the same, for each and every game fish, and for each and every deer or part of deer, killed or had in possession with the intention of sending or transporting the same, or having the same sent or transported beyond the limits of this state. And in addition to the fine, or fines, prescribed in this section, the person, or persons convicted may be confined in the county jail not to exceed sixty days for each and every offense; and upon default of the payment of the fine and costs, 
shall be confined in the county jail until the same are paid but not to exceed a period of sixty days.

Sec. 25a. It shall be uniawful for any person to chase, catch, kill or injure, or pursue with the intent to chase, catch, kill or injure any rabbit between the 20th day of December and the first day of November, both dates inclusive, of the following year, in the counties of Brooke, Hancock, Ohio, Marshall, Harrison and Marion. Any person violating any of the provisions of this section, shall be deemed guilty of a misdemeanor, and, upon conviction thereof, shall be fined not less than ten dollars nor more than twenty-five dollars for each offense, and in the discretion of the justice or court trying the case, be imprisoned in the county jail for a period not exceeding thirty days for each offense; and in default of the payment of the fines and costs, the person convicted shall be confined in the county jail for a period not exceeding twenty days unless such fine and costs be sooner paid.

Sec. 26. It shall be unlawful for any person to catch, kill or injure, or pursue with the intent to catch, kill or injure, any ruffed grouse or pheasant, or wild turkey between the first day of December and the fifteenth day of October of the following year; or any quail or Virginia partridge between the first day of December, and the first day 
of November following; nor any gray, black, red or fox squirrel between the first day of December and the thirty-first day of August, both inclusive, of the following year. Nor shall any person kill more than twelve quail or six ruffed grouse or two wild turkeys in any one day, nor more than ninety-six quail or twenty-five ruffed grouse or six wild turkeys in any one open season. No person shall kill any wild duck, wild goose or brant between the twentieth day of April and the first day of September; Provided, that the wood duck shall not be killed at any time within this state; woodcock, plover, rail, ortolan or sand piper between the twentieth day of December, and the fifteenth day of July following; or any snipe between the first day of March and the fifteenth day of October following.

It shall be unlawful for any person at any time to catch. by seine, net, bait, trap or snare of any kind or device, any wild turkey, ruffed grouse or pheasant or quail.

Any person violating any of the provisions of this section shall be guilty of a misdemeanor and, upon conviction thereof, shall be fined not less than twenty-five dollars nor more than fifty dollars for each offense, and in the discretion of the justice or court trying the case, be imprisoned in the county jail for a period not exceeding thirty days for each offense; and in default 
of the payment of the fine and costs, the person convicted be confined in the county jail for a period not exceeding thirty days unless such fine and costs be sooner paid. Provided, however, that the forest, game and fish warden or deputy wardens or other persons, under the direction of the warden may capture by any means any of the game birds or game animals to keep them alive for propagation purposes. And provided, further, that the warden may give written permission to any responsibble person, as provided by section thirty-eight of this chapter.

Sec. 27. ' It shall be unlawful for any person at any time to catch, by seine, net, bait, trap or snare of any kind or device, any wild turkey, ruffed grouse or pheasant or quail.

Sec. 28. It shall be unlawful to hunt, catch, kill or injure or pursue with intent to hunt, catch, kill or injure, any wild animals or birds, or fish, on the first day of the week, commonly known as Sunday.

Any person violating any of the provis. ions of this section or section twenty-seven hereof shall be deemed guilty of a misdemeanor, and upon conviction thereof shall be fined not less than ten dollars nor more than twenty-five dollars, nd in default of the payment of fine and costs, be committed to the county jail for a period of not more 
than thirty days, unless said fine and costs are sooner paid.

Sec. 29. All prosecutions under this chapter shall be in the name of the state of West Virginia, before any court or justice, having jurisdiction, and the justice shall have concurrent jurisdiction with the circuit and other courts in all misdemeanors, and in any case in which the prosecuting attorney appears, a fee of ten dollars shall be allowed him, to be taxed as a part of the costs of the case, and collected off the defendant, in case he is convicted.

Sec. 30. Every person called as a witness in any case for the violation of any of the provisions of this chapter, shall be compelled to testify fully; but his testimony shall not be given in evidence against him in any prosecution for such offense; and no person against whom such witness shall so testify, shall be competent as a witness for the state in the prosecution against such witness for the same offense or matters to which said witness so testified, nor for any violation of any provision of this chapter alleged to have been committed before the commencement of the prosecution in which he is examined as such witness.

Sec. 31. All moneys collected and due the state, under and by virtue of the provisions of this chapter, shall be disposed of, as follaws: The net proceeds of all fines collect- 
ed from convictions of the violations of any section of this chapter, shall after the payment of the amounts fixed by this chapter to the proper deputy wardens and the costs as provided by law be paid into the state treasury and credited to the "school fund" of the state, and provided by the constitution; all other moneys due the state by virtue of any of the provision of this chapter shall be paid into the state treasury and credited to the "forest, game and fish protective fund."

Sec. 32. In all cases where any person has been indicted for the violation of any of the provisions of this chapter, and has escaped or removed to another state all costs of requisition and extradition papers and all other costs and expenses of securing and bringing such person back into this state, shall be charged as a part of the costs of prosecution against such person; and if such costs of requisition and extradition papers and expenses cannot be secured from such person, they shall be paid out of the "forest, game and fish protective fund."

Sec. 33. That no person shall within the state of West Virginia kill or catch or have in his or her possession, living or dead, any wild bird other than a game bird; or purchase, offer or expose for sale, transport for sale, transport or ship within or without 
the state, any such wild bird after it has been killed or caught, except as permitted by this chapter. No part of the plumage, skin $\odot r$ body of any bird protected by this section shall be sold or had in possession for sale, irrespective of whether said bird was captured or killed within or without the state. For the purpose of this chapter all the birds and species of birds named in section twenty-three of this chapter only shall be considered game birds.

Sec. 34. No person shall, within the state of West Virginia take or needlessly destroy or attempt to take or destroy the nest or eggs of any wild bird other than a game bird, or have such nest or eggs in his or her possession, except as permitted by this chapter.

Sec. 35. No person or persons or any corporation acting as a common carrier, its officers, agents or servants, shall ship, carry, take or transport, either within or beyond the confines of the state, any resident or migatory wild-non-game bird.

Sec. 36. Any person violating sections twenty-three, thirty-four and thirty-five shall be guilty of a misdemeanor and upon conviction thereof shall be fined not less than ten dollars and may be confined in the county jail at the discretion of the court or justice for a period of not more than thirty days. 
Sec. 37. Sections thirty-three, thirty-four and thirty-five of this chapter shall not apply to any person holding a certificate giving the right to take birds, their nests, or eggs, for scientific purposes only as provided for in section thirty-eight of this chapter.

Sec. 38. Certificate may be granted by the forest, game and fish warden to any properly accredited person of the age of fifteen years or upwards, permitting the holder thereof to collect birds, their nests, or eggs for scientific purposes only; the applicant for same must present to said officer written testimonials from two well-known ornithologists who must be residents of West Virginia, certifying to the good character, and fitness of said applicant to be entrusted with such privilege; must pay said officer one dollar to defray the necessary expenses attending the granting of such certificate, on proof that the holder of such certificate has killed any bird or taken the nest of any bird for other than strictly scientific purposes, his certificate shall become void and he shall be liable to a fine not exceeding one hundred dollars or imprisonment not exceeding thirty days or both, at the discretion of the court.

Sec. 39. The certificate authorized by section thirty-eight of this chapter shall expire on the thirty-first day of December of 
the year issued, and shall not be transferable.

Sec. 40. The English or European house sparrow, owls, hawks, eagles, crows and king fishers are not included among the birds protected by this chapter.

Sec. 41. Nothing in this chapter shall prevent a citizen of West Virginia from taking or keeping any wild non-game bird in a cage as a domestic pet; provided, that such bird shall not be sold or exchanged, or offered for sale or exchange, or transported out of this state.

Sec. 42. Whoever, while engaged in hunting or pursuing wild game or game birds, negligently or carelessly shoots or wounds or kills any human being, or any live stock shall be deemed guilty of a misdemeanor, and on conviction thereof, shall be fined not exceeding one thousand dollars, and in the discretion of the court trying the case, be confined in the county jail for a period of not exceeding one year.

Sec. 43. There shall be no open season on the following named game birds: Hungarian partridge, Reeve's pheasant, English pheasant, Lady Amherst's pheasant, Chinese pheasant, caporcailzie or any other foreign game birds introduced into this state by the wardens or any person or persons, or associations. It shall be unlawful for any person to catch, kill or injure, 
any of the species of the game birds mentioned in this section. Any person violating any provision of this section shall be deemed guilty of a misdemeanor, and upon conviction, shall be fined not less than twentyfive dollars nor more than fifty dollars and, in the discretion of the court or justice trying the case be confined in the county jail for a period of not more than sixty days; and upon default of the payment of fine and costs, he shall be confined in the county jail not less than twenty days, unless said fine and costs are sooner paid. Each bird shall constiute a separate offense.

Sec. 44. Ii shall not be iawiul for any person to catch or destroy any of the fish in the creeks or rivers in this state by means of a drag or other net, fish pots, weirs, traps, by sledging, sıooting or other devices (except by hook and line) at any time; Provided, however, that any person may set a trot line, the hooks on which shall not be less than two feet apart, and, that seines may be used in the Ohio River from the fifteenth day of November to the first day of March following, but each seine so used must be registered by the owner or user with the forest, game and fish warden and the size of mesh must be two inches from knot to knot. Nor snall it be lawful for any person to catch and have in his possession any jack salmon, commonly called 
jack fish, or any white salmon of less than seven inches in length, or any pike of less than ten inches in length, or any black bass less than seven inches in length or any trout less than five inches in length, or any fish caught out of season or caught in any manner prohibited by law. And all fish less than the length prescribed herein shall be returned to the water immediatly with as little injury as possible.

And the measurement of fish shall be from end of nose to center form of tail. It shall be unlawful to take or destroy any jack saimon, (commonly called jack fish or white salmon) in any manner between the fifteenth day of April and the fifteenth day of June of each year; or to catch or destroy any trout or land-lock salmon in any manner between the first day of September and the first day of April of each year. It shall not be lawful for any person to catch any black bass, green bass, willow bass, rock bass, pike or pickerel, or wall eyed pike (commonly known as salmon) between the fifteenth day of April and the fiftenth day of June of each year; except that in the counties of Brooke, Hancock and Ohio the time shall be from April fifteenth to May twenty-ninth of each year; nor shall any person catch or kill any of said fishes or fish at any other time during the year, save only with a rod, hook and line, except, 
It shall be lawful to eatch fish of the sucker variety known as suckers, carp, mullet, and red horse, by gig, spear, looping or in any other way at any time; it shall be unlawful to kill bass or any other game fish by spear, gig, shooting or skipping or jumping.

It shall not be lawful for any person to catch or destroy fish in any dam or pond the property of any person, except with the consent of the owner of such dam or pond unless such dam or pond be in some of the rivers in this state. But nothing in this chapter shall be construed as to prevent the catching of minnows or other small fish, except salmon, bass, shad and trout, by means of hand, or cast nets, to be used for angling or scientific purposes; nor to prevent the warden of the state or his deputies or any person with their or his consent from catching any fish at any time with nets or seines for the purpose of propagation or stocking other waters, nor to prevent any person from taking in any way fish from his private dam, spring or pond at any time.

Any person who shall knowingly willfully let the water out of any pond mentioned herein with the intent to take or injure fish therein, shall be guilty of a misdemeanor and shall be punished, upon conviction, by imprisonment in the county jail not less than one month nor more than six months, 
or by a fine not less than fifty nor more than two hundred dollars, or by both fine and imprisonment.

The owners or those in control of lands or rights in land, in or bordering upon any pond designated in this act, shall have erected and maintained in a conspicuous place along these ponds when they are un-enclosed, a sign at least a foot square and which shall have thereon the name of the party in control and the words "Trespassers warned off under penalties of the law." Any person who shall wilfully and wrongfully tear down, deface or injure the boards provided for in this section shall be guilty of a misdemeanor and liable to a penalty as hereinafter provided.

Any person violating any provision of this section, except as otherwise herein provided, shall be guilty of a misdemeanor and for every conviction thereof shall be fined not less than ten dollars nor more than one hundred dollars and may, at the discretion of the court or justice trying the case, be confined in the county jail not exceeding thirty days.

Sec. 45. It shall be lawful for any person at any time, to remove or destroy any nets, traps or other devices placed in any creeks, runs or rivers within this state, except registered seines in the Ohio river, as - provided for in this chapter, and the person 
or persons claiming ownership or possession of such nets, seines or other devices shall have no recourse at law against the party destroying the same.

It shall be unlawful for any person or persons, to be found upon the creeks or small streams of this state where fish are taken with seines, (except minnow seines) in their possession and if so found, such possession shall be prima facie evidence that the same were used unlawfully. In all prosecutions under this act it shall be prima facie evidence sufficient on the part of the state to show that the defendant was found upon the creeks or small streams where fish are taken with such seine in his possession.

Any person violating any of the above provisions of this section shall be guilty of a misdemeanor and upon conviction thereof shall forfeit such net or seine (which net or seine shall be destroyed by order of the justice or court), and pay a fine of not less than ten dollars nor more than fifty dollars or be confined in jail not exceeding thirty days.

- And no person. firm or rorporation, siall build, erect, keep or maintain any dam or anything in any river. creek or water course in this state, which shall in any way or manner prevent or obstruct the free and easy passage of fish up or down such river. 
creek or other water course without placing, building or erecting on such dam or other thing, a good and sufficient ladder or .way so planned or built as to allow all fish to easily ascend or descend the same; and said ladder or way shall be constructed upon plans and in a manner and at a place satisfactory of the forest, game and fish warden of the state of West Virginia. Any person, firm or corporation violating this provision shall be guilty of a misdemeanor and upon conviction thereof shall be fined not less than ten dollars nor more than fifty dollars; and each week shall constitute a separate offense; provided, that any person, firm or corporation now maintaining or keeping any such dam or other thing shall be allowed six months from the time this act shall take effect in which to comply therewith.

And it shall be the especial duty of saic forest, game and fish warden upon the in formation of the violation of this provision, to immediately investigate the same, and cause this provision to be fully carried out.

Sec. 46. It shall be unlawful for any person, firm or corporation to employ or hire in any way, directly or indirectly or by the use of money or other thing of value to induce or persuade any other person, firm or corporation to kill, catch or deliver to such first named or any other person, firm or 
corporation, any deer, wild turkey, quail, pheasant or ruffed grouse, or any other wild game or wild birds, or trout, bass, salmon or any other game fish, the sale of which game or fish is prohibited by this chapter, and the serving of any such birds, game or fish killed or caught in this state by any hotel, restaurant or other licensed place where meals are furnished for pay, shall be deemed a sale of such birds, game or fish.

And it shall be unlawful for any person, firm or corporation to kill, catch or deliver for money or other thing of value, either directly or indirectly any such game, birds or fish.

Any person, firm or corporation violating this section shall be guilty of a misdemeanor and upon conviction thereof shall be fined not less than ten nor more than fifty dollars and may be confined in the county jail at the discretion of the court or justice for a period of not exceeding thirty days, and each animal, bird or fish so served, killed, caught or delivered shall constitute a separate offense.

Sec. 47. It shall be unlawful for any person to kill or attempt to kill any fish by use of dynamite or any other explosive mixture, or by the use of any poisonous drug, substance, bait or food or by the use of electricity, lime or other thing of like nature. 
And the placing of any such article in any stream, pond or lake, shall be deemed and taken to be prima facie proof of intention to violate this section.

Any person violating this section shall be guilty of a felony and upon conviction thereof, shall be confined 'in the penitentiary for a period not less than six months nor more than two years, and may at the discretion of the court be fined not less than fifty nor more than two hundred dollars.

Sec. 48. It shall be uniawful for any person, firm or corporation to sell, give or furnish directly or indirectly any dynamite or any other explosive or killing mixture or . any poisonous drug, bait or food to any per son, when such person, firm or corporation knows or has reason to believe that such dynamite or other explosive or killing mixture or poisonous drug, bait or food are intended to be used for the prupose of kill. ing fish. Any person, firm or corporation violating this section shall be guilty of a misdemeanor and upon conviction thereof, shall for each offense, be fined not less than twenty-five nor more than one hundred dollars, and may at the discretion of the court be confined in the county jail not exceeding thirty days.

Sec. 49. It shall be unliwful for any person to shoot, hunt, fish or fowl upon the enclosed or unenclosed lands of another per- 
son or camp, peel trees, cut trees or timber, build fires or do any other act or thing thereon in connection with or auxiliary to shooting, hunting, fishing or fowling on such lands, without permission in writing of the owner, lessee or other person entitled to the possession of such lands or of the tenant or agent of such owner, lessee or person entitled to the possession thereof, duly authorized to give such written permission, and every person hunting, shooting, fishing or fowling upon such lands shall have such written permission with them when so doing.

Any person violating any provisions of this section shall be guilty of a misdemeanor, and upon conviction thereof shall be fined not less than ten dollars nor more than fifty dollars and may, in the discretion of the court or justice, be confined in the county jail not more than thirty days; and if any person be convicted a third time of such offense, he shall be confined in the county jail for a period of not less than three nor more than thirty days in addition to any fine imposed, and in all cases he shall be confined in the county jail until the fine and costs are paid; provided, that such time shall not exceed thirty days. It shall be lawful for the owner, lessee or the person entitled to the possession of such lands or the agent thereof to arrest any 
such person found violating this section and immediately take him before a justice of the peace for trial and such owner, lessee, person or agent are hereby vested with all the powers and rights of a deputy game warden for such purpose; and it is hereby made the duty of the wardon and all deputies to see that this section is enforced.

Sec. 50. It shall be unlawful for any person to shoot or discharge any fire arms in or across any public road in this state at any time or within four hundred feet of any school house or shoot or discharge any firearms on the lands of another on any lawn or orchard or on any pleasure ground or other ground which is directly appurtenant to or within six hundred feet of any occupied dwelling house. Any person violating this section shall be guilty of a misdemeanor and upon conviction thereof shall be fined not less than ten dollars nor more than fifty dollars or at the discretion of the court or justice be imprisoned not more than thirty days.

Sec. 51. The forest, game and fish warden shall be ex officio fire warden of the state of West Virginia, and all deputy wardens shall also be deputy fire wardens for their respective counties in which each may reside. In case of fire in or threatening to forest or woodland, the deputy fire wardens of the county, wherein such fire is, shall 
upon receiving notice thereof, forthwith attend and use all necessary means to confine and extinguish the same. He may destroy fences, plough land, or, in an emergency, set back-fires to check fire. He may hire volunteers or summon any resident of his county to assist in putting out fires. Any person summoned, who is physically able and refuses to assist, shall forfeit the sum of ten dollars as a penalty therefor. An action of trespass shall not lie against persons crossing or working upon lands of another to extinguish fire. In case a forest. fire burn over more than one acre of land the deputy fire warden of the county in which it occurs, shall make report thereof to the warden, giving the area burned over, the quiantity of timber, wood, logs, bark or other forest product, and of fences, bridges and buildings destroyed, with. an estimate of the value thereof. He also shall report the cause of such fire and the means used and. cost expended in putting it out.

Sec. 52. Deputy wardens shall receive the sum of two dollars per day for the time actually employed at forest fires and each county court may fix the price to be paid per day, not exceeding two dollars for services of laborers at forest fires in their respective counties, and serve notice thereof on the warden and the deputy wardens, resident in such county. All services rendered 
at forest fires shall be a charge against the county, and each deputy warden shall renrler within twenty days after such fire to the county court thereof a sworn statement of the time used by him at such fire with the location of the same and the names of all persons hired or summoned by him, who assisted him thereat, together with the time each worked and the county court shall pay such deputy warden and assistants out of the county funds, after it has examined such reports and is satisfied with the correctness thereof.

Sec. 53. Whoever by himself, or by his servants, agents, or guide, or as the servant, agent or guide of any other person, shall build any fire, or use an abandoned fire in a field, public or private road, or adjacent to, or in, any woods or forest in this state, shall, before leaving such fire, totally extinguish the same, and upon failure to do so, such person, or persons, shall be deemed guilty of a misdemeanor, and on conviction thereof shall be fined not less than twentyfive dollars nor more than one hundred dol lar's and the costs of the prosecution, and upon default in paying said fine and costs, shall be confined in the county jail not more than ninety days unless said fine and costs, be sonner paid. If any person, or persons, negligently set on fire, any woods, fields or lands within this state, so as thereby to oc- 
casion loss, damage or injury to any other person, he shall be guilty of a misdemeanor and on conviction thereof, shall be fined not less than fifty dollars nor more than five hundred dollars, and in the discretion of the justice or court trying the case, be imprisoned in the county jail not to exceed one year, and upon default in payment of the fine and costs, he shall be imprisoned in the county jail not to exceed six months, and if any person or persons wilfully set on fire any woods, fields or lands within this state, not his own so as to thereby occasion damage or injury to any other person he shall be guilty of a felony and on conviction thereof shall be confined in the penitentiary not less than one nor more than two years. Sec. 54. Every railroad company shall. on such part of its road as passes through forest lands or lánds subject to fires from any cause, cut and remove from its right of way along such lands, at least twice a year, all grass, brush and other inflammabie materials and employ in seasons of drought and before vegetation has revived in the spring, sufficient trackmen to promptIy put out fires on its rights of way; provide locomotives thereon with netting of steel or iron wire so constructed as to give the best practicable protection against the escape of fire and sparks from the smoke stacks thereof and adequate devices to prevent the escape of fire from ash pans and 
furnaces which shall be used on such locomotives.

No railroad company or employee thereof shalí deposit fire coals or ashes on its track or right of way near sur! lands. In case of fire on its own or neighboring lands, the railroad company shall use all practicable means to put it out. Engineers, conductors or trainmen discovering or knowing of fires in fences or other material along or near the right of way of the railroad in such lands, shall report the same at the first station to the station agent, and such station agent shall forthwith notify the nearest fire warden and use all necessary means to extinguish the same. And any officer or employee of a railroad company violating any provisions of this section shall be guilty of a misdemeanor and upon conviction thereof, shall be fined a sum not less than twenty nor more than two hundred dollars.

Sec. 55. The forest, game and fish warden in the name of the county in which any forest fire has occurred, and which has been extinguished or suppressed by his efforts, shall recover from the person or persons, firm or colporation, giving origin to such fire the amount so expended in extinguishing said fire and the costs thereof, and the same shall not bar the rights of damage between the parties thereto.

Sec. 56. All acts and parts of acts in conflict with this act are hereby repealed. 


\section{THE LACEY BIRD LAW.}

(Federal Law.)

An act to enlarge the powers of the department of agriculture, prohibit the transportation by interstate commerce of game killed in violation of local laws and for other purposes.

Be it enacted by the Senate and House of Representatives of the United States of America in Congress assembled, That the duties and powers of the department of agriculture are hereby enlarged so as to include the preservation, distribution, introduction and restoration of game birds and other wild birds. The secretary of agriculture is hereby authorized to adopt such measures as may be necessary to carry out the purposes of this act and to purchase such game birds and other wild birds as may be required therefor, subject, however, to the laws of the various States and Territories. The obiert and purpose of this act is to aid in the restoration of such bircls in those parts of the United States adapted thereto where the same have become scarce or extinct, and also to regnlate the introduction of American or foreign birds or animals in localities whire they have not heretofore existed.

The serretary of agriculture shall from 
time to time collect and publish useful information as to the propagation, uses and preservation of such birds.

And the secretary of agriculture shall make and publish all needful rules and regulations for carrying out the purposes of this act, and shall expend ior said purposes such sums as congress may appropriate therefor.

Sec. 2. That it shall be unlawful for any person or persons to import into the United States any foreign wild animal or bird except under the special permit from the United States department of agriculture; provide $\vec{a}$, that nothing in this section shall restrict the importation of natural history specimens for museums or scientific collections, or the importation of certain cage birds, such as domesticated canaries, parrots or such other species as the secretary of agriculture may designate.

The importation of the mongoose, the socalled "flying foxes" or fruit bats, the English sparrow, the starling, or such other birds or animals as the secretary of agriculture may from time to time declare injurious to the interest of agriculture or horticulture, is hereby prohibited, and such species upon arrival at any of the ports of the United States shall be destroyed or returned at the expense of the owner. The secretary of the treasury is hereby author- 
ized to make regulations for carrying into effect the provisions of this section.

Sec. 3. That it shall be unlawful for any person or persons to deliver to any common carrier or for any common carrier to transport from one State or Territory, or from the District of Columbia or Alaska to any State or Territory to the District of Columbia or Alaska, any foreign animals or birds the importation of which is prohibited, or the dead bodies or parts thereof of any wild animals or birds where such animals or birds have been killed in violation of the laws of the State, Territory or district in which the same were killed; provided, that nothing herein shall prevent the transportation of any dead birds or animals killed during the season when the same may be lawfully captured, and the export of which is not prohibited by law in the State, Territory or district in which the same are killed.

Sec. 4. That all packages containing such dead animals, birds, or parts thereof, when shipped by interstate commerce, as provided in section one of this act, shall be plainly and clearly marked, so that the name and address of the shipper and the nature of the contents may be readily ascetained on inspection of the outside or such packages. For eåch evasion or violation of this act the shipper shall, upon conviction, pay a fine of not exceeding two hundred dollars; 
and the consignee-knowingly receiving such articles so shipped and transported in violation of this act shall, upon conviction, pay a fine not exceeding two hundred dollars and the carrier knowingly carrying or transporting the same shall, upon conviction, pay a fine of not exceeding two hundred dollars.

Sec. 5. That all dead bodies, or parts thereof, of any foreign game animals, or game or song birds, the importation of which is prohibited or the dead bodies or parts thereof, of any wild game animals, or game or song birds transported into any State or Territory, or remaining therein for use, consumption, sale or storage therein, shall upon arrival in such State or Territory be subject to the operation and effect of the laws of such State or Territory enacted in the exercise of its police powers, to the same extent and in the same manner as though such animals and birds had been produced in such State or Territory, and shall not be exempt therefrom by reason of being introduced therein in original packages or otherwise. This act shall not prevent the importation, transportation, or sale of birds or bird plumage manufactured from the feather's of barnyard fowl.

Approved May 25, 1900. 
$D$ 



\section{LIBRARY OF CONGRESS}

||||||||||||||||||||||||||

0002876263 A 